\title{
TINDAK TUTUR DIREKTIF INTERAKSI GURU DAN ANAK PADA TAMAN KANAK-KANAK DI KABUPATEN GOWA
}

\author{
${ }^{1}$ Muhammad Nawir, ${ }^{2}$ Gusnawaty, ${ }^{3}$ Asriani Abbas \\ ${ }^{123}$ Program Studi Bahasa Indonesia, Fakultas Ilmu Budaya, Universitas Hasanuddin, Makassar \\ nawiryudu89@gmail.com \\ gusnawatyanwar@gmail.com \\ asriani.abbas66@gmail.com
}

\begin{abstract}
This study discusses the comparison of language style in novel Atheist by Achdiat Karta Miharja and novel Telegram by Putu Wijaya. The aims of this study are (1) to describe the embodiment of language styles in novels Atheist and novels Telegram, and (2) to describe the comparison of language styles in novels Atheist and novels Telegram. This research is a qualitative research using descriptive method. The approach used in this research is stylistic approach. Sources of data in this study is a text that contains the style of rhetorical language and figurative style of language. The results show that: (1) the style of language used in the novel Atheist is the style of language; Hyperbole, simile, metaphor, personification, antonomasia, and sarcasm. The style of language found in the novel Telegram namely; Hyperbole, simile, metaphor, personification, antonomasia, and metonimia. Based on the language style found, there are three types of word classes used as word choice in realizing the style of figurative language and style of rhetorical language, namely; Nouns, verbs, and adjectives. (2) The similarity between novels Atheist and novels Telegram is the similarity of hyperbola-style, personification, and antonomasia-forming structures. The difference between the novel Atheist and the novel Telegram lies in the metaphorical style marker which in the novel Atheist is a transitive verb, while in the novel Telegram is a concrete noun.
\end{abstract}

Keywords: Style of language, novel Atheis, novel Telegram.

\section{PENDAHULUAN}

Pemakaian bahasa dapat dijumpai dalam berbagai segi kehidupan, termasuk di dalamnya bahasa yang dipakai dalam suatu pembelajaran di lembaga pendidikan. Keberhasilan suatu program pembelajaran ditentukan oleh beberapa komponen yang harus saling berinteraksi. Menurut Sudjana (1989:41) pembelajaran adalah suatu proses terjadinya interaksi antara guru dan siswa.

Pendidikan taman kanak-kanak menjadi amat instrumental bagi pendidikan di sekolah dasar dan jenjang pendidikan selanjutnya. Menurut Sumantri (2005:14) taman kanak-kanak merupakan salah satu jenis lembaga atau instansi pendidikan formal. Umur rata-rata anak-anak belajar di taman kanak-kanak berkisar 4-6 tahun. Usia ini merupakan usia yang sangat menentukan dalam pembentukan karakter dan kepribadian. Usia dimana anak mengalami pertumbuhan dan perkembangan yang pesat.
Oleh karena itu sebagai lembaga pendidikan prasekolah, pendidikan taman kanak-kanak ditekankan pada pemberian rangsangan pendidikan untuk membantu pertumbuhan dan perkembangan jasmani dan rohani agar anak memiliki kesiapan dalam memasuki pendidikan lebih lanjut yaitu pada pendidikan sekolah dasar.

Sesuai dengan Peraturan Pemarintah Nomor 27 Tahun 1990 pasal 3 (dalam Sumantri, 2005:6): Tentang pendidikan prasekolah bertujuan untuk membantu meletakkan dasar ke arah perkembangan sikap, pengetahuan, keterampilan, dan daya cipta yang diperlukan oleh anak didik dalam menyesuaikan diri dengan lingkungan dan untuk pertumbuhan dan perkembangan selanjutnya. Pemerintah berperan aktif dalam memfasilitasi kegiatan pendidikan anak usia prasekolah. Makadari itu pendidikan prasekolah adalah pendidikan untuk membantu pertumbuhan dan perkembangan 


\section{4 | JURNAL ILMU BUDAYA}

Volume 6, Nomor 1, Juni 2018

jasmani dan rohani anak didik di luar lingkungan keluarga sebelum memasuki pendidikan dasar yang diselenggarakan di jalur pendidikan luar sekolah.

Guru sebagai pengajar yang baik harus dapat memunculkan gairah belajar murid agar melakukan aktivitas belajar. Dalam hubungannya dengan aktivitas karena doronga 'n oleh adanya faktor-faktor kebutuhan biologis, insting, dan mungkin unsur kejiwaan yang lain, serta adanya pengaruh kebudayaan manusia. Agar dalam kegiatan belajar dapat terarah seorang guru memiliki peran yang sangat penting guna menciptakan kondisi atau suatu proses yang baik. Guru melakukan usaha-usaha untuk dapat menumbuhkan motivasi agar anak didiknya melakukan aktivitas dengan baik. Untuk dapat belajar dengan baik diperlukan proses dan motivasi yang baik pula. Memberikan motivasi kepada seorang anak didik berarti menggerakkan mereka untuk melakukan sesuatu atau ingin melakukan sesuatu.

Isjoni (2010: 19) mengemukakan bahwa anak usia 4-6 tahun merupakan bagian dari anak usia dini yang secara terminologi disebut sebagai anak usia prasekolah. Usia demikian merupakan usia peka bagi anak. Pada masa ini terjadinya pematangan fungsi-fungsi fisik dan psikis yang siap merespon stimulasi yang diberikan oleh lingkungan.

Peneliti tertarik untuk meneliti tindak tutur direktif guru pada anak usia prasekolah (3-6 tahun). Tindak tutur direktif meminta yang digunakan oleh guru cenderung menyuruh atau memerintah anak-anak untuk melakukan sesuatu sesuai aba-aba dengan menggunakan pola tuturan langsung supaya mudah dipahami lawan tutur. Hal ini dikarenakan kedudukan guru lebih tinggi dari anak-anak. Sementara itu, tindak tutur yang digunakan oleh anakanak cenderung meminta atau memohon kepada ibu guru supaya mengabulkan keinginannya. Hal ini dikarenakan kedudukan anak-anak lebih rendah atau tidak berdaya untuk melakukan sesuatu dengan sendiri.

Menurut Searle (dalam Rahardi, 2006: 36) tindak tutur direktif (directives), yakni bentuk tutur yang dimaksudkan penuturnya untuk membuat pengaruh agar si mitra tutur melakukan tindakan, misalnya meminta, bertanya, memerintah, melarang, memberi izin, menasihati. Lebih lanjut Searle (1969) mengungkapkan bahwa direktif itu dapat langsung (yaitu dengan menggunakan kalimat bermodus imperatif) dan dapat pula tidak langsung (yaitu dengan menggunakan kalimat bermodus bukan imperatif).

Pragmatik merupakan cabang ilmu bahasa yang semakin dikenal pada masa sekarang ini, walaupun pada kira-kira dua dasa warsa yang silam, ilmu ini jarang atau hampir tidak pernah disebut oleh para ahli bahasa. Hal ini dilandasi oleh semakin sadarnya para linguis, bahwa upaya untuk menguak hakikat bahasa tidak akan membawa hasil yang diharapkan tanpa didasari pemahaman terhadap pragmatik, yakni bagaimana bahasa itu digunakan dalam komunikasi menurut Leech, (1993: 1).

Purwo (1990: 16) mendefinisikan pragmatik sebagai telaah mengenai makna tuturan utterance menggunakan makna yang terikat konteks. Sedangkan memperlakukan bahasa secara pragmatik ialah memperlakukan bahasa dengan mempertimbangkan konteksnya, yakni penggunaannya pada peristiwa komunikasi.

Pragmatik juga diartikan oleh Kridalaksana, (1993: 177) sebagai syaratsyarat yang mengakibatkan serasi-tidaknya pemakaian bahasa dalam komunikasi; aspekaspek pemakaian bahasa atau konteks luar bahasa yang memberikan sumbangan kepada makna ujaran. Menurut Verhaar (1996: 14), pragmatik merupakan cabang ilmu linguistik yang membahas tentang apa yang termasuk struktur bahasa sebagai alat komunikasi antara penutur dan pendengar, dan sebagai pengacuan tanda-tanda bahasa pada hal-hal "ekstralingual" yang dibicarakan.

Pragmatik merupakan cabang ilmu linguistik yang mengkaji makna berdasarkan konteks. Yule (1996) membahas konteks dalam kaitannya dengan kemampuan seseorang untuk mengidentifikasi referenreferan yang bergantung pada satu atau lebih pemahaman orang itu terhadap ekspresi yang diacu. Berkaitan dengan penjelasan tersebut, Yule membedakan konteks dan koteks. Konteks ia definisikan sebagai lingkungan fisik dimana sebuah kata dipergunakan. Koteks menurut Yule adalah bahan linguistik yang membantu memahami sebuah ekspresi atau ungkapan. Koteks adalah bagian linguistik dalam lingkungan tempat sebuah ekspresi dipergunakan. 
125 | JURNAL ILMU BUDAYA

Volume 6, Nomor 1, Juni 2018

Menurut Leech konteks didefinisikan sebagai aspek-aspek yang berkaitan dengan lingkungan fisik dan sosial sebuah tuturan. Leech menambahkan dalam definisinya tentang konteks yaitu sebagai suatu pengetahuan latar belakang yang secara bersama dimiliki oleh penutur dan petutur dan konteks ini membantu petutur menafsirkan atau menginterpretasi maksud tuturan penutur.

Sehubungan dengan penggunaan tindak tutur direktif penelitian ini menggunakan teori yang diajukan oleh Searle dalam menjelaskan bentuk tutur yang dimaksudkan penuturnya untuk membuat pengaruh agar si mitra tutur melakukan tindakan, misalnya meminta, bertanya, memerintah, melarang, memberi izin, menasihati. Untuk memudahkan analisis penelitian ini maka peneliti akan menjelaskan tindak tutur direktif interaksi guru dan anak pada taman kanak-kanak di kabupaten gowa dalam lingkup kajian pragmatik.

\section{METODE PENELITIAN}

\section{Jenis Penelitian dan Pendekatan}

Penelitian ini merupakan penelitian kualitatif yang bersifat deskriptif. Penelitian deskriptif digunakan untuk mendeskripsikan fakta-fakta berupa tindak tutur direktif interaksi guru dan anak usia prasekolah. Penelitian ini merupakan penelitian yang menggunakan pendekatan pragmatik dengan memfokuskan pada bahasa yang digunakan untuk berkomunikasi dalam situasi tertentu. Leech (1972) dalam (Nadar, 2009: 2) mengungkapkan bahwa kajian pragmatik menekankan pada dua tipe makna yaitu intended meaning 'makna yang diinginkan oleh penutur' dan interpreted meaning 'makna yang diinterpretasikan oleh mitra tutur' yang ada dalam pikiran mitra dalam mengolah dan membuat interpretasi yang diperolehnya saat memperoleh informasi ketika sedang berkomunikasi. Adapun menurut Levinson (1983: 9), pragmatik sebagai kajian hubungan antara bahasa dan konteks yang tergramatikalisasi atau terkodifikasi dalam struktur bahasa.

Penelitian ini memfokuskan pada jenisjenis tindak tutur direktif dan faktor-faktor penyebab tindak tutur direktif guru yang diterbitkan oleh anak usia prasekolah maupun bentuk-bentuk dan faktor-faktor tindak tutur direktif yang dipahami oleh anak usia prasekolah. Penelitian ini melibatkan pengasuh sebagai penutur dan anak sebagai mitra tutur maupun anak sebagai penutur dan pengasuh maupun temannya sebagai mitra tutur. Bentuk interaksi berupa komunikasi antara pengasuh dan anak tentu saja melibatkan konteks atau situasi tutur, sehingga jelaslah penelitian ini merupakan penelitian pragmatik.

\section{Sumber dan Jenis Data}

Sumber data yang digunakan untuk penelitian ini adalah ujaran guru taman kanakkanak di Kabupaten Gowa sedangkan jenis data penelitian ini adalah data lisan, berupa tuturan d guru taman kanak-kanak yang mengandung tindak tutur direktif.

\section{Lokasi dan Waktu Penelitian}

Lokasi penelitan yaitu di Kabupaten Gowa, yang meliputi taman kanak-knak berikut: TK Ulil Albab di BTN Nuki Pallangga, TK Mulia Jasa di BTN Andi Tonro Permai, TK Mawar di Jalan Abdul Muthalib Dg.Narang, TK Arrahim di Jalan Abdul Muthalib , TK Citra Samata di Jalan Samaung Dg. Ngemba No.47. Peneliti menetap di lokasi penelitian untuk mengumpulkan data yang diperlukan. Oleh karena itu, waktu penelitian yang dibutuhkan adalah tiga minggu.

\section{Metode dan Teknik Pengumpulan Data}

Metode yang digunakan untuk mengumpulkan data dalam penelitian ini adalah metode observasi. Observasi adalah studi yang disengaja dan sistematis tentang fenomena sosial dan gejala-gejala psikis dengan jalan pengamatan dan pencatatan. Observasi sendiri diarahkan pada kegiatan berbahasa dengan memperhatikan secara akurat, mencatat fenomena yang terlihat, mempertimbangkan hubungan antaraspek dalam fenomena tersebut dengan mengamati objek kajian dalam konteksnya. Dari metode tersebut, teknik yang dapat digunakan untuk mendukung metode obeservasi yaitu (1) teknik rekam, yaitu teknik yang digunakan untuk merekam tuturan guru taman kanak-kanak, dengan bantuan alat perekam, yakni berupa telepon gengam; (2) teknik catat, yaitu datadata yang telah dikumpulkan melalui teknik rekam selanjutnya dilakukan pencatatan.

\section{Teknik Analis is Data}

Analisis data merupakan suatu proses mengatur urutan data, mengorganisasikannya kedalam suatu pola, kategori, dan satuan uraian dasar. Data yang telah diperoleh melalui hasil rekaman, kemudian dianalisis dengan menggunakan metode deskriptif, yaitu 
126 | JURNAL ILMU BUDAYA

Volume 6, Nomor 1, Juni 2018

penggambaran kenyataan yang ditemukan sebagaimana adanya. Proses analisis dilakukan melalui tahap, mengidentifikasi data tuturan guru dan murid yang ditemukan dalam interaksi guru dan murid pada Taman Kanakkanak di kabupaten Gowa. Setelah data ditemukan, langkah selanjutnya yaitu mengklasifikasikan data berdasarkan permasalahan yang ada, yakni jenis-jenis tindak tutur direktif. Data yang telah diklasifikasi, selanjutnya diurutkan sesuai dengan tujuan penelitian yang ingin dicapai. Tahap selanjutnya, data dianalisis dengan pendeskripsian secara mendetail permasalahan yang terdapat dalam data, berdasarkan teori yang berkaitan dengan tindak tutur direktif sebagai dasar pedoman analisis, tahap terakhir adalah menyimpulkan hasil analisis data dari permasalahan yang ada.

\section{HASIL PENELTIAN}

Hasil penelitian ini secara umum berkaitan dengan aspek kebahasaan yang terjadi di wilayah kabupaten Gowa. Aspek kebahasaan tersebut yakni tindak tutur direktif yang terdapat pada interaksi interaksi guru dan anak pada taman kanak-kanak.

Penelitian ini mengungkapkan bahwa tindak tutur direktif yang terdapat pada interaksi interaksi guru dan anak pada taman kanak-kanak di Kabupaten Gowa meliputi: jenis permintaan (requstives), pertanyaan (questions), perintah (requirements), larangan (prohibitive), dan nasihat (advisories). Adapun faktor-faktor yang memengaruhi tindak tutur direktif interaksi guru dan anak pada taman kanak-kanak di Kabupaten Gowa antara lain karena tidak memerhatikan guru, ribut, bermain, tidak fokus, lelah, dan menangis. Peneltian ini belum menjelaskan secara menyeluruh fenomena tindak tutur direktif yang terdapat pada interaksi interaksi guru dan anak pada taman kanak-kanak di Kabupaten Gowa.. Pemahaman tentang tindak tutur direktif yang terdapat pada interaksi interaksi guru dan anak pada taman kanak-kanak di Kabupaten Gowa akan diuraikan pada pembahasan berikut.

\section{PEMB AHASAN}

Penelitian ini menemukan bahwa tindak tutur direktif yang terdapat pada interaksi interaksi guru dan anak pada taman kanakkanak di Kabupaten Gowa cukup beragam. Hal ini karena anak-anak tidak memerhatikan guru, ribut, bermain, tidak fokus, lelah, dan menangis. Data yang menunjukkan temuan tindak tutur direktif yang terdapat pada interaksi interaksi guru dan anak pada taman kanak-kanak di Kabupaten Gowa, yakni sebagai berikut.

Tindak tutur requstives menunjukkan bahwa dalam mengucapkan sesuatu tuturan, penutur meminta kepada mitra tutur untuk melakukan suatu perbuatan. Penutur mengekspresikan keinginan dan maksud agar mitra tutur melakukan tindakan atas keinginan penutur. Tindak tutur requstives dapat dilihat pada data berikut.

Data (1)

Guru : Mukni...Mukni, ayo Mukni naik kesini

Murid : (langsung naik menuju papan tulis)

Konteks

Percakapan ini terjadi setelah jam istirahat usai dan guru kembali memberikan tugas kepada murid. Pada saat proses belajar berlangsung, salah satu murid bernama Mukni tidak memperhatikan pelajaran.

Tuturan guru pada data (1) di atas mengekspresikan keinginan guru yang meminta agar muridnya mau maju ke depan kelas untuk mengerjakan soal yang diberikan oleh guru. Jika penutur menyikapi permintaan dengan ekspresi sungguh-sungguh atau mengharapkan tuturannya dipatuhi, maka mitra tutur diharapkan segera melaksanakan apa yang diinginkan oleh penutur. Tuturan permintaan guru ditandai dengan penggunaan kata ayo yang mengandung makna mengajak.

Tindak tutur questions mengandung pengertian bahwa penutur memohon kepada mitra tutur agar memberikan informasi tertentu. Berdasarkan ciri formalnya pola intonasi kalimat tanya ditandai dengan tanda (?). Ciri lain yang menandai kalimat tanya adalah penggunaan kata tanya seperti: apa, siapa, dimana, kapan, mengapa dan bagaimana. Tindak tutur questions dapat dilihat pada data berikut.

Data (5)

Guru : Fahrul mana daguta kita nak ?

Murid (Fahrul) : Diam

Konteks

Setelah guru meminta murid untuk menyebutkan nama-nama anggota tubuh, salah satu murid bernama Fahrul tidak ikut menyebutkan nama-nama anggota tubuh 


\section{7 | JURNAL ILMU BUDAYA}

\author{
Volume 6, Nomor 1, Juni 2018
}

tersebut. Guru pun mengajukan pertanyaan kepada Fahrul dengan menanyakan letak dagu.

Pada data (5), interaksi berupaya dibangun oleh guru terhadap muridnya yang bernama Fahrul. Data (5) merupakan tuturan pertanyaan yang memerlukan jawaban. Penutur mengekspresikan keinginan atau permintaan kepada mitra tutur untuk memberikan jawaban suatu penjelasan. Penutur mengharapkan jawaban dari pertanyaan yang diberikan. Tuturan pertanyaan pada data (5) ditandai dengan penggunaan kata tanya mana yang mempunyai maksud agar mitra tutur (murid) menjawab letak dagu yang ditanyakan oleh guru.

Tindakan requirements mengindikasikan bahwa ketika mengucapkan suatu tuturan, penutur menghendaki mitra tutur untuk melakukan perbuatan. Penutur mengekspresikan keinginan bahwa ujarannya dalam hubungan dengan posisi di atas mitra tutur, merupakan alasan yang cukup bagi mitra tutur untuk melakukan tindakan. Penutur mengekspresikan maksud agar mitra tutur melakukan tindakan (paling tidak sebagian dari) keinginan penutur. Tindakan requirements dapat dilihat pada data berikut.

Data (21)

Guru : laki-laki dulu yah, silahkan ambil tasnya

Murid : (langsung berdiri)

Konteks

Memasuki waktu makan, guru memerintahkan semua murid untuk berdiri mengambil tas yang berisi bekal.

Data (22)

Guru : yang sudah kenyang silahkan atur kembali tasnya.

Murid : (tidak menjawab)

Konteks

Setelah makan, guru menginstruksikan untuk mengatur kembali tas di rak. Murid tidak menjawab, namun ada beberapa murid yang langsung berdiri untuk menyimpan tasnya.

Data (21) menunjukkan proses interaksi yang dilakukan oleh guru kepada muridnya. Apa yang diekspresikan oleh guru adalah kepercayaan bahwa ujarannya mengandung alasan yang cukup bagi murid untuk segera melakukan tindakan. Guru sebagai penutur memberi anggapan bahwa dia memiliki kewenangan yang lebih tinggi daripada murid. data tersebut diekspresikan melalui bentuk perintah dengan mengarahkan yang ditandai melalui kata silahkan. Untuk memberi petunjuk, arahan, tuntunan dari penutur ke mitra tutur agar melaksanakan suatu hal. Mitra tutur diharapkan mampu melaksanakan tugas setelah diberikan arahan.

Data tuturan (21) mengandung perintah dengan pengarahan agar laki-laki terlebih dahulu mengambil tas. Tuturan perintah yang dikemukakan guru direspon oleh murid lakilaki dengan perbuatan yakni dengan langsung berdiri mengambil tasnya. Namun, tidak semua tuturan perintah yang dinyatakan oleh guru didengar dan direspon oleh murid.

Tindakan prohibitive merupakan suatu tindakan yang menunjukkan bahwa ketika mengucapkan suatu ekspresi penutur melarang mitra tutur untuk melakukan tindakan. Tindakan prohibitive dapat dilihat pada data berikut.

Data (34)

Guru : coba tidak diganggu dulu temannya

Data (35)

Ini huruf apa Zaidan?

Guru : Tidak boleh meluncur-luncur kepala tapi pantat nah.

Selanjutnya pada data (34) dan (35) pola kalimat larangan yang diujarkan ditandai dengan kata tidak. Data (34) tersebut merupakan tuturan larangan yang diekspresikan guru kepada murid agar tidak mengganggu temannya yang lain yang sedang mengija huruf. Adapun data (35) menunjukkan tuturan larangan guru kepada muridnya untuk tidak meluncur-luncur menggunakan kepala tetapi menggunakan pantat.

Tindak advisories adalah tindak ketika mengucapkan suatu ekspresi, penutur menasehati mitra tutur untuk melakukan tindakan. Penutur mengekspresikan kepercayaan bahwa terdapat alasan bagi mitra tutur untuk melakukan tindakan dan penutur mengekspresikan maksud agar mitra tutur mengambil kepercayaan penutur sebagai alasan baginya untuk melakukan tindakan. Tindak advisories dapat dilihat pada data berikut.

Data (35)

Guru :Kalau mencuri, tangannya dipotong. 


\section{8 | JURNAL ILMU BUDAYA}

Volume 6, Nomor 1, Juni 2018

Data (36)

Guru :Kita tidak boleh

mendengar bisikan setan

Kita akan melanjutkan ke hafalan hadist

Hadist menuntut ilmu !

Murid :(langsung melafalkan

hadist)

Data (37)

Guru : silahkan ubah posisi duduknya, meskipun duduk kita tetap harus sopan.

Murid : udztasah, kalau kasi tugas yang tarik-tarik garis

Data (38)

Guru : jangan malu

Data (35) sampai dengan (38) merupakan interaksi yang dilakukan guru kepada siswa. Tuturan guru di atas mengekspresikan kepercayaan bahwa ujarannya mengandung maksud yang baik bagi kepentingan siswa. Tuturan tersebut mengekspresikan alasan yang kuat bagi murid untuk melaksanakan apa yang diujarkan, karena kedudukan guru lebih tinggi sebagai pemberi nasihat.

Tuturan guru pada data (35) bertujuan memberikan nasihat kepada murid untuk tidak mencuri karena kalau mencuri tangan dipotong. Begitupun halnya pada tuturan data (36), guru menasehati murid agar tidak mendengar bisikan setan. Adapun data (37) dan (38) guru memberikan nasehat untuk tetap sopa meskipun sedang duduk serta menasehati agar tidak malu.

\section{SIMPULAN}

Berdasarkan hasil penelitian dan pembahasan, dapat disimpulkan bahwa tindak tutur direktif yang terdapat pada interaksi interaksi guru dan anak pada taman kanakkanak di Kabupaten Gowa meliputi: jenis permintaan (requstives), pertanyaan (questions), perintah (requirements), larangan (prohibitive), dan nasihat (advisories). Adapun faktor-faktor yang memengaruhi tindak tutur direktif interaksi guru dan anak pada taman kanak-kanak di Kabupaten Gowa antara lain karena tidak memerhatikan guru, ribut, bermain, tidak fokus, lelah, dan menangis. Peneltian ini belum menjelaskan secara menyeluruh fenomena tindak tutur direktif yang terdapat pada interaksi interaksi guru dan anak pada taman kanak-kanak di Kabupaten Gowa. Oleh karena itu, penulis sarankan Bagi peneliti lain yang hendak melakukan penelitian, akan lebih baik mengambil waktu

penelitian tidak bertepatan dengan bulan Ramadhan dan dalam pengambilan data memakai alat bantu rekam lebih dari satu. Hal ini dimaksudkan agar data yang didapat lebih akurat. Bagi pembelajaran di sekolah, penggunaan tindak tutur direktif yang dituturkan guru dan siswa agar lebih ditingkatkan untuk menciptakan interaksi belajar mengajar yang lebih aktif.

\section{DAFTAR PUSTAKA}

Isjoni. 2010. Model Pembelajaran Anak Usia Dini. Banung. Alfabeta.

Kridalaksana, Harimurti. 1993. Катиs Linguistik. Jakarta: Gramedia

Leech, Geoffrey. 1983. Prinsip-prinsip Pragmatik. Jakarta: Universitas Indonesia.

Purwo, Bambang K. 1990. Pragmatik dan Pengajaran Bahasa. Yogyakarta: Kanisius.

Rahardi, Kunjana. 2002. Pragmatik Kesantunan Imperaktif Bahasa Indonesia. Jakarta: Penerbit Erlangga.

Searle, Jhon R. 1969. Speech Act An Essay on the Philosophy of Language. New York: Cambridge University Press.

Sudjana, Nana. 1989. Penelitian Hasil Proses Belajar Mengajar. Bandung: PT. Remaja Rosdakarya.

Sumantri. 2005. Model Pengembangn Keterampilan Motorik Anak Usia Dini. Jakarta: Depdiknas Dirjen PT PDPTK.

Verhaar, J.W.M. 1996. Asas-asas Linguistik Umum. Yogyakarta: Gadjah Mada University Press.

Yule, George. 1996. Pragmatik. Terjemahan oleh Wahyuni, Indah Fajar. 2006. Yogyakarta: Pustaka Pelajar. 